\title{
A methodology of strategic analysis for servitization of the manufacturing company
}

\author{
JUSTYNA KOZLOWSKA
}

\author{
Faculty of Engineering Management \\ Bialystok University of Technology \\ 45A Wiejska Street, Bialystok 15-351 \\ POLAND
}

\begin{abstract}
Servitization in manufacturing companies often involves reformulating or building new strategies. It is a complex and challenging process that is very prone to failure if carried out without careful strategic planning. The scientific literature strictly regarding strategic analysis methodology in the context of servitization is rather limited. Only a few studies were identified which indicate strategic analysis methods that are useful for building servitization strategies. Whereas the catalog of methods for strategic analysis is wide and varied. Therefore, this study aims to fill this gap and give an answer to the following research question: How to conduct a strategic analysis (with which methods and tools) so that the obtained information would improve the decision-making process in the context of servitization in manufacturing? A survey conducted in the Polish machinery manufacturing sector shows that there is a relationship between conducting strategy analysis in the context of product-service activity and the level of service income in manufacturing companies. Likewise, if the company analyzed service-related business areas along with the product-related, it has reported an increase in service income in recent years. Based on these findings and the outcomes of the review of servitization strategies and the conditions of successful implementation of these strategies, the author developed an 8-stage methodology of strategic analysis. It enables to gather the most relevant and needed information about the company resources and its environment to facilitate making decisions in the context of product and service integration. An original tool for assessing the orientation of organizational culture is proposed. The developed methodology was verified by application in two manufacturing companies, and that allowed to formulate a list of recommendations for future application of the methodology.
\end{abstract}

Key-Words: servitization, servitization of manufacturing, strategic analysis, product-service integration methodology, strategic management

Received: August 1, 2020. Revised: November 30, 2020. Accepted: December 16, 2020. Published: January 12, 2021

\section{Introduction}

Competitive pressure and rapid technological progress increase the importance of innovation and the need to use up-to-date knowledge in manufacturing companies. Only those organizations that can offer unique solutions for their industry have a chance to compete successfully with others. Unique solutions cannot be based solely on innovation in the technological context, as they are usually quite quickly imitated by other companies in the industry. Manufacturing companies see such an opportunity in service activities. They integrate services as an addon to their products or as a part of a product-service solution offered to their clients. This kind of expansion, however, triggers a process of many changes and brings a series of consequences for the manufacturer's activity, business model, and customers [1]. Services require the entrepreneur to introduce new rules, structures, and organizational processes. Developing new skills and opportunities also requires redirecting financial and managerial resources from the sphere of manufacturing and development of new products to the sphere of development of services or product-service integration [2]. As a consequence, manufacturers need to reformulate or build a new strategy for their organization and plan how to implement and monitor its successful realization. Therefore, service innovations in product-based companies are issues of great importance that imply strategic management. The phenomenon of the shift of product-oriented companies into service-oriented organizations is 
known in the scientific literature as inter alia, servitization of manufacturing, product-service integration, and product-service system [3]. There are plenty of different terms and definitions related to this research field. For example, Ren \& Gregory advocate the process approach defining servitization as: "a change process wherein manufacturing companies embrace service orientation and/or develop more and better services, with the aim to satisfy customer's needs, achieve competitive advantages and enhance firm performance" [4]. While Baines et al. define that servitization means innovation in manufacturer capabilities and the process of a shift from selling products to selling integrated product-service offerings [5]. Whereas, Manzini \&Vezzoli define a product-service system as: 'an innovation strategy, shifting the business focus from designing (and selling) physical products only to designing (and selling) a system of products and services which are jointly capable of fulfilling specific client demands' (PSS) [6]. Therefore, in this paper, the term servitization will be used interchangeably with the term product-service integration, and is understood as: "all systematic activities undertaken by manufacturing companies aimed at increasing the scope of services provided, which create added value for the customer and the company, in their current product-oriented offering". The definition emphasizes the aspect of decisionmaking activity - that is, the need to take several actions and decisions by manufacturing companies towards expanding service activities, which will create added value for both the entrepreneur and users or customers. Many studies indicate the importance of strategic management in the servitization process [e.g. 7-9]. Product-service integration requires introducing many changes at the management level, which usually relate to five areas in the company: the product offer, final output, relationships with customers, relationships with suppliers, and perception of the company [10]. The changes are challenging, far-reaching, multi-stage, and complex. Therefore, to avoid wrong decisions or failures in the servitization of the company activity, the process of implementation of all changes related to product and service integration must be preceded by a thorough planning process, including strategic planning [11-13].

The three main components of the strategic management process, i.e., analyses, decisions, and actions, are usually defined in practice as stages: strategic analysis, design/formulation of the strategy, and implementation of the strategy. Strategic analysis is the starting point of the strategic management process, which is necessary to effectively formulate and implement strategies. Many strategies implemented without a prior thorough analysis of the organization's overarching objectives and analysis of its external and internal environment fail [14]. Formulating the strategy affects and involves various functional levels of the organization, from business units (areas of an organization's operation) dealing with strategies with a limited scope, through functional levels, to the highest levels dealing with the global management of the organization and the formulation of international strategies. Strategy implementation usually involves making profound changes in the organization to modify all its subsystems so that they fit with the strategic goals and support their implementation. It involves making decisions that relate to the allocation of resources in the areas of the company's activity characterized by development potential, changes in the organizational structure, and management of changes in the areas where they occur in the organization [15].

Integrating services into a corporate strategy in a product-oriented company is a challenge but also a necessity to ensure the successful servitization [8]. Although the strategic management of the servitization process is quite well described in the literature, studies discussing its first stage - the strategic analysis - remain scarce. In particular, there is a very limited number of studies that address the problem of choosing relevant methods and tools for strategic analysis when a company wants to assess the possibilities and capabilities of changing towards providing a wider range of services or more advanced product-service offerings. To fill this research gap, the following research question was formulated:

$R Q$ : How to conduct a strategic analysis (with which methods and tools) so that the obtained information would improve the decision-making process in the context of servitization in manufacturing? To answer the research question, the following methodology of this study was designed and implemented. First, a vast scientific literature review in the context of strategic management and strategic analysis in the context of servitization. At the same time, a survey was carried out among 150 Polish machinery manufacturing companies. Manufacturers were asked in the questionnaire about their service activity, habits in conducting strategic analysis, and the share of service income in the total company revenue. Then, 10 in-depth interviews were conducted with experts in the servitization field to identify key factors influencing the process of product-service integration in manufacturing companies. Based on literature review results supported by the empirical study outcomes, the author developed a methodology of strategic analysis suitable for manufacturing 
companies that would like to build new strategies aimed at service and product integration. The proposed methodology was applied and verified in two manufacturing companies what allowed to develop recommendations about its future applications.

\section{Strategic analysis and service income of manufacturing companies in Poland - correspondence analysis results}

The survey was conducted among 150 representatives of management from the machine and equipment manufacturing sector in Poland with the use of the CATI (Computer-Assisted Telephone Interview) technique and a structured questionnaire. Companies were chosen randomly. According to the results of the survey, more than $80 \%$ of machine and equipment manufacturers offer services, but they focus mainly on product-oriented services as an addon to the product offer. About $1 / 4$ of them offer services that generate over $30 \%$ of their total income. As far as strategic analysis is concerned, over $50 \%$ of manufacturers use various methods and tools for such analyses, while $49 \%$ claim that they do not conduct strategic analysis, mainly because they do not see the need for it and sometimes a parent company or a central unit deals with analyses. Moreover, small companies rarely carry out strategic analysis, whereas big enterprises do that much more often.

Respondents were also asked which area of activity (product-related, service-related, or both) they usually analyzed. Only two manufacturers indicated that service activity is the subject of strategic analysis in their company. A small group of respondents (21 manufacturers, representing 14\% of the total surveyed group, and $27 \%$ of those who perform strategic analysis) uses different methods of strategic analysis for production and service activity. While, 68 manufacturers (i.e., $88 \%$ of those who use strategic analysis, which accounts for $45 \%$ of the total research sample) examine the area of manufacturing activity only (Table 1).

Table 1. Areas of activity that are the subject of strategic analyses in surveyed companies

\begin{tabular}{|c|c|c|c|c|c|c|}
\hline \multicolumn{7}{|c|}{ Do you use any strategic analysis tools/methods? } \\
\hline & Yes & No & Total & Yes & No & Total \\
\hline & 77 & 73 & 150 & $51 \%$ & $49 \%$ & $100 \%$ \\
\hline \multicolumn{7}{|c|}{$\begin{array}{c}\text { Which areas of activity are the subject of strategic } \\
\text { analyses in your company? }\end{array}$} \\
\hline $\begin{array}{l}\text { Product } \\
\text { related } \\
\text { activity }\end{array}$ & 68 & 82 & 150 & $45 \%$ & $55 \%$ & $100 \%$ \\
\hline
\end{tabular}

\begin{tabular}{|c||c|c|c||c|c|c|}
\hline $\begin{array}{c}\text { service } \\
\text { related } \\
\text { activity }\end{array}$ & 2 & 148 & 150 & $1 \%$ & $99 \%$ & $100 \%$ \\
\hline $\begin{array}{c}\text { product- } \\
\text { service } \\
\text { related } \\
\text { activity }\end{array}$ & 21 & 129 & 150 & $14 \%$ & $86 \%$ & $100 \%$ \\
\hline
\end{tabular}

Source: author's research.

In the context of strategic planning, machine manufacturers who make strategic decisions based on the performed analyses use mainly methods of examining the organization's resources. Macroenvironmental analyses are seldom used, as they are relatively more expensive and difficult to carry out in the perspective of surveyed manufacturers. In this way, however, many opportunities appearing in the environment are not perceived at all or recognized too late. Consequently, an opportunity to build a strategy for competitive advantage is lost. Servitization is relatively often the answer to market opportunities, so an insufficient analysis of the environment may not identify such opportunities on time or underestimate their importance.

Information gathered during the survey allowed also to examine the relationship between strategic analyses and service income in the manufacturing companies under investigation. Respondents were asked to estimate the share of service income in the total company's revenue and to indicate whether this share changed (increased/decreased/remained unchanged) over the last five years. As the information gathered could be coded as qualitative variables, the author chose a chi-square test and correspondence analysis for the relationship examination. Correspondence analysis is a descriptive and exploratory technique for the analysis of cross- and multidivisional tables, which allows finding connections between qualitative variables [16]. The following variables were selected for analysis:

- Y1 - percentage share of revenue from services in the total revenue; variable categories: $0-15 \%, 15-$ $20 \%, 21-30 \%, 31-40 \%, 41-50 \%$ and over $50 \%$;

- Y2 - change in revenue from services; variable categories: increased, decreased, unchanged;

- X1 - areas of activity that are subject to strategic analyses, variable categories: $\mathrm{p}$ (product-related), $\mathrm{p}-\mathrm{s}$ (product/service-related), n/a (do not apply).

Chi-square test results between $\mathrm{X} 1$ and $\mathrm{Y} 1$ and between $\mathrm{X} 1$ and $\mathrm{Y} 2$ are presented in Table 2.

Table 2. Results of a chi-square test

\begin{tabular}{|l|c|c|c|}
\hline Statistics measure & $\chi^{2}$ & df & p \\
\hline \multicolumn{4}{|c|}{ Statistics: X1 (3) x Y1 (6) } \\
\hline Pearson's $\chi^{2}$ & 35,922 & 10 & 0,00009 \\
\hline
\end{tabular}




\begin{tabular}{|l|c|c|c|}
\hline Cramér's V & 0,37028 & & \\
\hline \multicolumn{4}{|c|}{ Statistics: X1 (3) x Y2 (3) } \\
\hline Pearson's $\chi^{2}$ & 18,0735 & 4 & 0,00119 \\
\hline Cramér's V & 0,26265 & & \\
\hline
\end{tabular}

Source: author's research.

The results of the chi-squared independence test indicate that between variable X1 (conducting strategic analysis by the company) and both other variables - the level of share of service activities in total revenue and it changes over the last five years there is a statistically significant dependence. The strength of these relationships, based on the Cramer's V statistics, can be considered as weak to moderate. Then, the correspondence analysis was carried out. Its results can be presented graphically on perception maps which facilitates conclusion. Judging by the position of the points in the plot (Figure 1), it may be concluded that the greatest dependence is shown between the categories "p-s" of the first variable and categories "41-50\%" and "over 50\%" of the second variable. They have the closest coordinate values in 1 dimension, which is dominant, judging by the eigenvalue, and these points are the most distant from other categories. Therefore, it can be stated that a manufacturer who claimed to carry out the strategic analysis for product-service-related activity also relatively more frequently indicated a share of the revenue from services at the level of more than $40 \%$ than entrepreneurs choosing other answers (namely analyzing product-related activities or conducting no analyses at all).

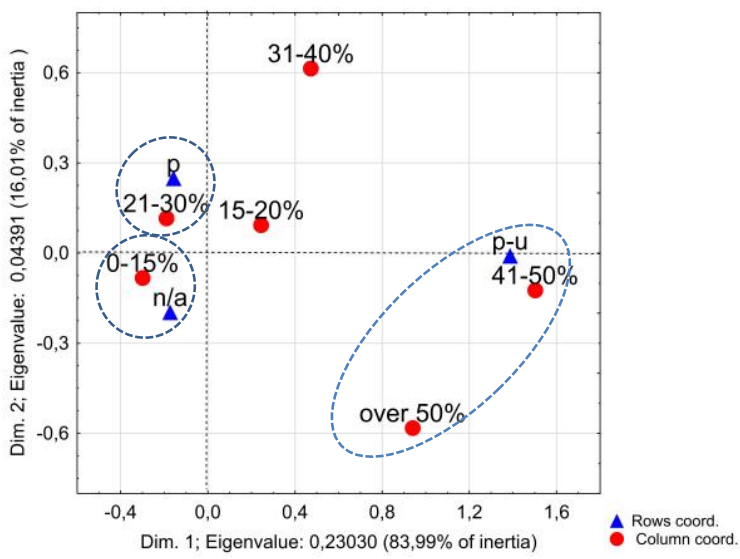

Figure 1. Map of perception for variables X1 and Y1 (correspondence analysis results)

Source: author's research.

Additionally, taking into account the 2nd dimension, the categories " $p "$ and " $\mathrm{n} / \mathrm{a}$ " are on the opposite sides of 0 and might be associated respectively with the categories " $21-30 \%$ " and " 0 $15 \%$ " of the second variable. Therefore, these answers (circled in the plot) relatively more often appeared in the answer of one respondent. It is difficult to combine the categories "15-20\%" and "31-40\%" with a certain category of Y1. However, it can be stated that entrepreneurs who do not perform any strategic analyses have, relatively more often, the lowest revenues from services.

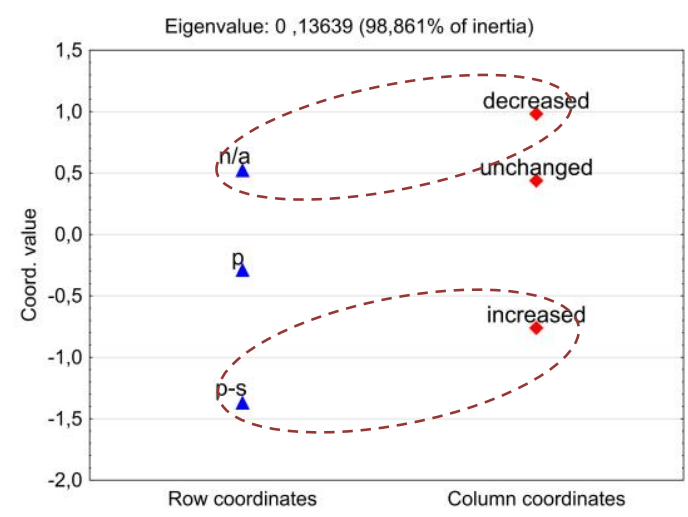

Figure 2. Map of perception for variables X1 and Y2 (correspondence analysis results)

Source: author's research.

Figure 2 presents the map of perception for $\mathrm{X} 1$ and Y2. It can be stated that the increase in revenue from services over the last 5 years was relatively most frequently observed in companies using the strategic analysis method to the product-service activity. The "n/a" category is most strongly associated with "decreased" so it can be concluded that these responses were most common to appear in one manufacturer's answers. The application of strategic analysis to product-related activities ("p") cannot be undisputably combined with the category "increased" or "unchanged" due to the very similar distance to both points in the plot.

To sum up, the results of the chi-squared test and the correspondence analysis indicate that there is a relationship between strategic analysis in companies and financial results related to service activities. The nature of these relationships is illustrated by perception maps. It was proved that companies conducting strategic analysis concerning product and service activity reported higher revenues from services and likewise an increase in these revenues in recent years. Moreover, manufacturers who do not perform strategic analysis at all showed the lowest percentage share of the revenue from services in the total revenues of the company and relatively more often reported a decrease in service income in recent years than the rest of the surveyed companies. The obtained results justify the need to conduct strategic analyses in manufacturing companies that are expanding their service activities and intend to modify their business model in this direction. 


\section{Strategic analysis in the context of servitization}

The company's identity, the skills and characteristics of its employees, and the relative strength of external stakeholders (suppliers, competitors, and/or local authorities) can greatly influence the company's decision about the expansion of its service activity. Most of these factors relate to the functioning of the organization in the long run. They include key management issues such as management style, structure and values, how to hire, train, and reward staff, and how to build and manage relationships with external stakeholders. The company's current situation is a starting point for the future. A meaningful assessment of the manufacturer's situation and its strategic position is a prerequisite for achieving its goal of effectively developing service activity.

\subsection{Strategic analysis in the process of product and service integration}

Strategic analysis is, from a functional perspective, a set of activities diagnosing the organization and its environment, which will allow it to build a strategic plan and carry out its implementation. From an operational perspective, it is a set of methods allowing to examine, evaluate, and predict the future state of the company and its environment taking into account its ability to survive and develop.

There are few or narrowly focused studies on the early stages of strategic planning concerning servitization in the literature. Therefore, the number of guidelines for a comprehensive strategic analysis that would provide complete information for making decisions related to the scope and scale of productservice integration is limited. For example, Ziout and Azab indicated the usefulness of the PESTEL (Political, Economic, Social, Technological, Environmental, and Legal factors) analysis for the study of the company's macro environment for product and service integration [17]. Van Ostaeyen, Neels, and Duflou listed the following methods: PEST/STEP (Political, Economic, Social, and Technological factors) analysis, Porter's 5 forces analysis, market segmentation, product life cycle analysis, and value chain analysis [18] as adequate for designing a service-oriented business model in a product-oriented organization. French author Mathieu believes that it is good practice to use the benchmarking method, not only for initial strategic analysis but also at different stages of product and service integration [19].
The catalog of strategic analysis methods and tools is very wide [20-24] and the range of information obtained during the analyses is varied. Therefore, it seems appropriate to identify those methods and tools which allow gaining knowledge that will facilitate making strategic decisions about servitization. The effectiveness of strategic analysis can only be measured by assessing the extent to which it achieves its basic objective, which is to discover the key external and internal conditions that are crucial for future development. Performing a strategic analysis in a standard way may result in neglecting or underestimating the key areas that determine the success of the implementation of the chosen servitization strategy.

\subsection{Connections between strategic analysis and building and implementation of servitization strategies}

A fundamental sequence of basic stages of strategic management leads from analysis, through the stage of making strategic decisions, to translating them into action. However, some other interdependencies and relationships disrupt the linearity of this process. For example, the implementation of a strategy can inspire new concepts. And strategic analysis not only precedes the process of concept formulation and implementation of the strategy but also serves to examine the consequences of the actions taken and the new conditions accompanying their implementation. Therefore, individual stages of strategic management should be carried out continuously and during their implementation, they should be directly linked to the remaining stages and at the same time provide them with up-to-date, new information [14].

In the literature, a lot of servitization strategies were identified and described [4, 25]. Each strategy is focused on different aspects of providing services or product-service solutions, determining various goals. Thus, it requires a diverse configuration of resources, capabilities, and competences inside the company. Strategy formulation also requires such information as the product offer and its potential for services and the alignment of current strategic goals with the servitization strategy. It is also crucial to decide how the service process and service activities related to the products can be realized - inside the company organization structure with the use of its capabilities, or by outsourcing all or part of the service activities outside the company, and building strategic alliances. [19]. This choice is determined by the company's relationship and human resources, and technical and 
organizational capabilities. It should be then assessed by strategic analysis.

Due to the substantial differences between the culture of product-oriented and service-oriented organizations [25], one of the strategic aims in product-service integration is often to build a service culture in a manufacturing company. Organizational culture is pointed out as a crucial issue in the successful servitization of manufacturers. The orientation of organizational culture on services in manufacturing companies reflects the problem of overcoming the "cultural" habits of product manufacturers. The process of servitization requires the development of different service awareness among both managers and employees. Increased awareness of services at the managerial level leads to a change in service awareness at the employee level, which triggers new cultural behavior patterns across the organization [26]. The organizational culture of manufacturing companies is a weak point in the process of product and service integration. Entrepreneurs in the industry sector have a strong technological orientation that makes it difficult to build and shape a service-oriented organizational culture. And a service-oriented organizational culture helps to bridge the gap between what an organization can achieve by training its employees and what the customer ultimately expects [7]. This aspect should be also a subject of detailed strategic analysis.

The implementation stage of the strategy of productservice integration includes the following strategic activities: planning and allocation of the organization's resources, taking into account service activities, adaptation of the organizational structure, including manufacturing processes and service providing processes, and management of strategic changes in the organization. The integration of services and products into a systemic solution is a paradigmatic change in defining service performance already at the stage of engineering design and technical solutions by considering both components, tangible and intangible goods, in an integrated manner [27]. Strategic analysis should provide information on the needs and expectations of customers in terms of product-related services and the assessment of the need to organize the design processes of such services, as well as the capabilities and abilities of the organization in this area, both in terms of intangible resources (knowledge and skills and human resources) and technical (necessary infrastructure, hardware, and software). Furthermore, along with the development of service activity in the manufacturing company, the customer commitment to the design process increases [28]. Thus, knowledge of methods for designing services and employee competences in this field as well as customer involvement or willingness to get involved in the design process should be subject to strategic analysis. Effective implementation of the productservice integration strategy in the organization is conditioned by an appropriate value proposition for the customer in the service component, which should meet the specific needs and requirements of customers [29]. To plan and design new productservice solutions that take into account the value of services, manufacturers need tools based on an approach that includes creating lasting relationships with customers. The familiarity with tools and competencies in building relationships with the client and knowledge of basic or most important processes in customer organizations should be assessed during strategic analysis for servitization purposes.

Linkage of the successive stages of strategic management of product and service integration with strategic analysis indicates the need to examine the relevant areas and obtain a range of information during the process, which was included in the developed methodology presented in the next section.

\section{Methodology of strategic analysis for a manufacturing company in the context of servitization}

Based on the above discussion of literature review results, eight key aspects of the company activity have been identified: current product offer of the company and its potential, organization's objectives and strategy, intangible resources of the organization, relationship resources, organizational culture orientation, organizational and technical area, microenvironment and macro environment. To make it more specific, in-depth interviews were conducted with representatives of Polish machinery manufacturers with few-year experience in service providing, and academic researchers with experience in the servitization field. Experts assessed a catalog of factors developed by the author from the literature studies [see the other author's work: 30] grouped into 7 sets according to the STEEPVL scheme. STEEPVL is an acronym that refers to factors: Social, Technological, Economic, Ecological, Political, Values, Legal. STEEPVL is a useful foresight method for the analysis of key factors (both internal and external) that may influence a researched phenomenon [31] and is widely adapted to many studies of different nature due to its generality and comprehensiveness [32-36]. The assessment of factors by experts allowed to build a list of the 18 most important factors that determine the servitization of the companies operating in the 
machinery manufacturing sector, which are as follows:

$\mathbf{S}$ - social factors: staff specialized in the provision of services, global and local trends in consumer behavior (e.g. fashion);

$\mathbf{T}$ - technological factors: technology in the scope of product manufacturing, product architecture, product complexity level, technology/product life cycle phase;

$\mathbf{E}$ - economic factors: economic benefits for service recipients, energy and material consumption throughout the product life cycle, costs of providing services, competition in the market;

E - ecological factors: environmental standards related to recycling of machinery and equipment, the concept of sustainable development;

$\mathbf{P}$ - political factors: the organization's strategy, legal regulations for the provision of long-term services, defined service strategy;

V - value: long-term and stronger relationships, building and maintaining a customer service culture, creating value propositions for the client;

$\mathbf{L}$ - legal factors: legal data protection.

Experts also pointed out some other factors not included in the catalog. All these factors should be evaluated at a certain stage of strategic analysis. Thus, they were taken into consideration while setting the goals of each stage and selecting the methods and tools for the proposed in this study methodology.

\subsection{Methodology of strategic analysis for product-service integration}

The methodology of strategic analysis for gathering relevant information for product-service integration in a manufacturing company consists of 8 main stages (Figure 3), with not obligatory preliminary stage 0 and the synthesis of information and knowledge acquired during the whole analytical process. It follows the standard scheme of the strategic analysis process, first including the study of the company's macroenvironment (Stage 1) and micro-environment (Stage 2, Stage 3, and Stage 4) and consequently - analysis of the company's resources (Stage 5, Stage 6, Stage 7 and Stage 8). For each stage, there are relevant methods and tools chosen, specific questions indicated which should be answered, and factors that should be assessed.

Stage 0. The purpose of the initial, optional stage is to examine the current state of advancement of the process of product and service integration in the company. The awareness of the progress of the servitization process is sometimes low since services are seen as a secondary activity to the manufacturing activity. It may turn out that both the catalog of provided services and the share of the revenue from services are much larger than the producers think, and only detailed analysis or comparison with other manufacturers reveals the volume of this activity and its importance in the overall activity of the company. The evaluation of the maturity level can be performed according to any model available in the literature. However, the author recommends a relatively easy to use the original model of classification of the manufacturer's level of maturity in the provision of services, according to which it is necessary to determine the number of different types of services in the offer and the share of revenue from the provision of services in total revenue [see: 37 ].

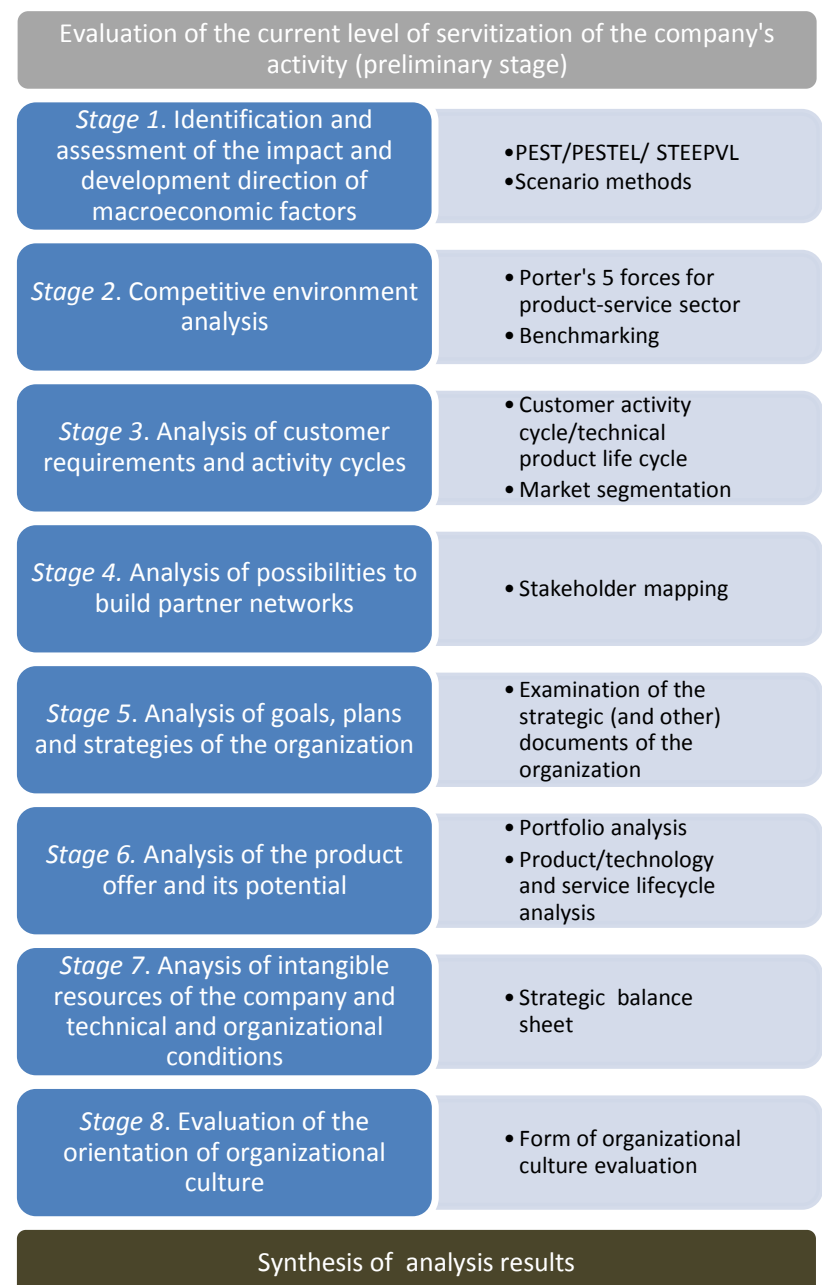

Figure 3. Scheme of the methodology for strategic analysis for product-service integration in a manufacturing company with operational guidelines Source: author's research

Stage 1. The first stage aims to answer the question: What are the directions of development of trends related to product and service integration in the macroenvironment? Key factors influencing the processes of product and service integration in the macroenvironment of the company according to the experts are global and local trends in consumer 
behavior (e.g. fashion); the level of innovation of production technologies; environmental standards related to recycling of machinery and equipment; the concept of sustainable development; legal regulations for the provision of long-term services; legal protection of data; the level of wealth of the society; the cost of maintaining qualified employees; environmental impact of industrial services; legal protection of service consumers; and European Union policy on innovative solutions in the industry. This list was prepared based on experts' opinions, but the users of the methodology may generate and analyze their own set of factors using STEEPVL analysis approach. At this stage, a scenario method with the scenario-axes technique [38] is strongly recommended. Scenarios allow for the logical and formal construction of alternative visions of the desired future of the organization, taking into account the knowledge and understanding of the factors shaping the studied phenomenon, and thus enabling rational decision making about the future [39].

Stage 2. The diagnosis of a competitive microenvironment aims to obtain answers to questions: Do and how do the competitors develop services? What segments of the service market do the competitors serve? The method recommended in stage 2 is the analysis of Porter's 5 forces, which should be focused on the sector or industry concerning a new area - services in manufacturing. Additionally, a lot of information and guidance can be obtained by analyzing in detail how global corporations and industry leaders from other countries develop their service activities. Thus, using the method of observation and benchmarking is suggested.

Stage 3. This stage aims to obtain answers to the questions: Will the external environment and all stakeholders accept product and service integration and its results? Are customers willing to purchase more services? What are their main/up-to-date requirements and needs? What can be offered to customers, taking into account the product lifecycle? What new service market segments can be addressed? What are the main business/production processes in the potential/current customer organization? Factors that have proven to be key to assess at this stage include customers' willingness to purchase services, the level of wealth of society (including customers), economic benefits for service users, creating value propositions for the client, length, durability and strength of the relationship, the reputation and image of the company. This is one of the most important stages of the methodology, which manifests itself in the number of questions to be answered. Partially, these questions can be taken into consideration in Porter's 5 forces analysis. However, additional methods that are worth accompanying the results of the previous stage are analysis of the customer's activity cycle combined with the analysis of the technical product lifecycle [40] and market segmentation.

Stage 4. The fourth stage aims to answer the following questions: What relational external resources does the enterprise have and what are the possibilities of creating partner networks? What kind of cooperation in the field of service provision can be established (outsourcing, partnership)?

The method recommended at this stage is stakeholder mapping [41]. It allows understanding the underlying relationships and level of commitment of individual units and external organizations to the enterprise. Stakeholders may be customers, cooperators, banks, offices, suppliers, competitors, and institutions. In the context of product and service integration, it is worth considering both current and potential stakeholders in the analysis, as well as creating two maps.

Stage 5. The main goal of the stage is to answer the question: To what extent is the product-service integration compatible with the current company's strategy? However, questions helpful at this stage might be the following: Is there a reference to service activities in the organization's strategy? What financial objectives does the organization pursue? Do they (objectives) include service activities? What is the orientation of the main activities and processes in the company visible - on the customer, on production or services? The technique that can be used at this stage is the examination of the organization's documents, with particular emphasis on the strategic documents, describing its mission, vision, as well as short- and long-term plans. Nevertheless, equally valuable information can be obtained from other seemingly unrelated documents (notes from meetings, reports, etc.).

Stage 6. The aim of stage 6 is to obtain detailed information on the current product and service offers, as well as their potential, mainly in terms of service portfolio development. The main premise for the analysis of the portfolio of manufactured products and their life cycle is to link the range of services with the product life cycle. Therefore, the methods potentially applicable at this stage are portfolio analyses and analysis of phases of the product and/or technology lifecycle but also the service lifecycle (if there are services in the current offering). The product lifecycle can be considered in the technical and market context. A combination of these two approaches is also recommended to identify potential areas for services 
Stage 7. In this stage of the strategic analysis, it is necessary to assess intangible resources, excluding the examination of the organizational culture, and technical and organizational resources. This stage aims to obtain answers to questions: Does the organization have adequate resources to introduce new or develop the current product and service offer? To what extent do the organizational structure and decision-making levels meet the needs of sales and after-sales service of product and service offers? To what extent do employees' skills, knowledge, and approaches meet the requirements of the process of providing services or delivering product-service offers to customers? Can the principles of introducing innovations in the company be adapted to both the development of material products and the introduction or development of services? The recommended method of assessing the organization's resources, taking into account their different nature, is a strategic balance sheet $[23,42]$. It is a rather complicated and expensive method, however, it can be simplified and enriched with the information crucial from the perspective of the manufacturer on the product-service integration path.

Stage 8. In the penultimate stage of the proposed methodology, the orientation of organization culture should be examined. This stage aims to answer the question: Should and to what extent the service culture in the organization be changed and shaped? Organizational culture is an intangible resource of the company, but it was excluded from the previous stage due to its importance in the servitization process and because there is a very limited number of strategic analysis tools that focus on the cultural aspects precisely. Therefore, the author proposes a tool that may be used for such examination and would provide necessary information about the orientation of the corporate culture in the organization. The tool was designed based on the synthesis of the literature studies presented in Section 3.2. of this article, and the review of studies focused on the organizational culture and its assessment [43-46]. The tool consists of 16 opposite statements (Table 3) which need to be assessed on a 7-point scale. The average assessment below 4 informs about the product-oriented organizational culture. While the average result above 4 means that organizational culture is serviceoriented.

Table 3. A form for organizational culture evaluation

\begin{tabular}{|c|c|c|}
\hline In our organization & 1234567 & In our organization \\
\hline $\begin{array}{l}\text { Employees are reluctant to } \\
\text { engage in taking up new } \\
\text { challenges }\end{array}$ & & $\begin{array}{l}\text { Employees willingly } \\
\text { engage in taking up new } \\
\text { challenges }\end{array}$ \\
\hline
\end{tabular}

\begin{tabular}{|c|c|c|}
\hline In our organization & 1234567 & In our organization \\
\hline $\begin{array}{l}\text { There is a strong } \\
\text { resistance to changes } \\
\text { related to the expanding } \\
\text { the area of the } \\
\text { organization's activities }\end{array}$ & & $\begin{array}{l}\text { There is little resistance to } \\
\text { changes related to the } \\
\text { expansion of the } \\
\text { organization's area of } \\
\text { activity }\end{array}$ \\
\hline $\begin{array}{l}\text { Money and items are } \\
\text { important }\end{array}$ & & People are important \\
\hline $\begin{array}{l}\text { Independence is } \\
\text { appreciated }\end{array}$ & & $\begin{array}{l}\text { People depend on each } \\
\text { other }\end{array}$ \\
\hline $\begin{array}{l}\text { Internal relations are } \\
\text { important }\end{array}$ & & $\begin{array}{l}\text { Internal and external } \\
\text { relationships are just as } \\
\text { important }\end{array}$ \\
\hline $\begin{array}{l}\text { Customer relationships are } \\
\text { short-lived }\end{array}$ & & $\begin{array}{l}\text { Relationships with the } \\
\text { client are long-lasting }\end{array}$ \\
\hline $\begin{array}{l}\text { A high level of technical } \\
\text { knowledge is important }\end{array}$ & & $\begin{array}{l}\text { Communication skills are } \\
\text { important }\end{array}$ \\
\hline $\begin{array}{l}\text { The training and } \\
\text { motivation system is } \\
\text { oriented to product } \\
\text { development }\end{array}$ & & $\begin{array}{l}\text { The training and incentive } \\
\text { system is oriented towards } \\
\text { the development of } \\
\text { services }\end{array}$ \\
\hline $\begin{array}{l}\text { Achievement is defined in } \\
\text { terms of quick profit }\end{array}$ & & $\begin{array}{l}\text { Achievement is defined in } \\
\text { terms of long-term } \\
\text { collaboration with partners }\end{array}$ \\
\hline $\begin{array}{l}\text { Contact with stakeholders } \\
\text { is focused on the } \\
\text { implementation of tasks }\end{array}$ & & \begin{tabular}{|l} 
Contacts with stakeholders \\
are focused on building \\
long-term relationships \\
\end{tabular} \\
\hline $\begin{array}{l}\text { Intrapersonal values } \\
\text { dominate }\end{array}$ & & $\begin{array}{l}\text { Interpersonal values } \\
\text { dominate }\end{array}$ \\
\hline $\begin{array}{l}\text { Services are seen as } \\
\text { "necessary evil" }\end{array}$ & & $\begin{array}{l}\text { Services are seen as an } \\
\text { added value }\end{array}$ \\
\hline $\begin{array}{l}\text { Success is guaranteed by a } \\
\text { good quality product }\end{array}$ & & $\begin{array}{l}\text { Success depends on the } \\
\text { service package }\end{array}$ \\
\hline $\begin{array}{l}\text { Strong faith in the } \\
\text { potential of the product is } \\
\text { demonstrated }\end{array}$ & & $\begin{array}{l}\text { Strong belief in the } \\
\text { potential of services is } \\
\text { demonstrated }\end{array}$ \\
\hline $\begin{array}{l}\text { Attention is paid to the } \\
\text { production results }\end{array}$ & & $\begin{array}{l}\text { Attention is paid to the } \\
\text { relationship with the } \\
\text { customer }\end{array}$ \\
\hline $\begin{array}{l}\text { The product offer depends } \\
\text { on internal capabilities } \\
\text { and resources }\end{array}$ & & $\begin{array}{l}\text { The product offer includes } \\
\text { services and is flexibly } \\
\text { adjusted to the needs of } \\
\text { the market }\end{array}$ \\
\hline
\end{tabular}

Note for user: please assess in each row which statement (left or right) is more suitable for your organization

Source: author's original work.

Synthesis of analysis results. It is worthwhile to finally make a summary of the information obtained, which will facilitate the creation of strategic alternatives and its design. The SWOT method is relatively suitable here. In the context of the strategic analysis of product and service integration, carried out according to the proposed methodology, it becomes a simple compilation of all obtained results. In a simple version, it consists of a list of the main strengths and weaknesses of the organization and the threats and opportunities created by external conditions, and such a version can be used to summarize the most important results of all analyses conducted so far. 


\subsection{Recommendations for the application of the methodology in manufacturing companies}

The proposed methodology was verified by application in two Polish companies. Both are operating in the machinery manufacturing sector and represent the SME sector. Manufacturers carried out the analyses on their own, consulting it from time to time with the author. The most problematic step appears to be Stage 1 due to uncertainty in the assessment and identification of key macroeconomic factors that are crucial for the sector. The author recommended them to focus on the set of factors which were identified and evaluated during the qualitative studies. A somewhat interesting observation was that there are major differences between the assessments of the orientation of the organizational culture between departments and organizational levels. The management and marketing department in one of the companies assessed the organizational culture as more productoriented than employees of the construction or production department. Therefore, employees of typical product-oriented departments seem to have a more service-oriented and client-oriented approach than marketing employees. Moreover, all suggested graphical tools such as maps and graphs were considered helpful to understand clearly the outcomes of the analysis.

In general, manufacturers evaluated the developed set of methods and tools as useful $h$ informative for the company, not only in terms of product and service integration. Based on the results of the research and verification of the methodology, the following recommendations for its application were developed.

1. To ensure the triangulation of information and knowledge, the analysis team should be composed of several people, at least one of whom should represent the external environment, and another one should be independent and unrelated to the company. Besides, the team should include both high and middle-level managers as well as regular employees.

2. Key external and internal factors need to be verified first, due to the different economic conditions of the regions where manufacturing companies operate. Even if companies operate in the same market in terms of the customer, they may have completely different development conditions due to, for example, functioning in a special economic zone or zones covered by special development programs.

3. Each step must be carefully documented, and the results are described as comprehensively as possible. Graphical presentation of the results of the analyses at each stage is an additional facilitation in interpreting the acquired information and making conclusions towards designing a strategy of product and service integration.

4. Small manufacturing companies may encounter difficulties in objectively assessing external factors. Therefore, it is recommended to have an external expert at least at stage 1 of the methodology. The next stages can be carried out on your own.

5 . The examination of the organizational culture should be conducted with the involvement of as many employees from different levels and positions as possible. It should also be carried out separately in the different departments of the company and on different levels, as these evaluations vary according to the employee's perspective. The most complete organizational culture assessment requires the involvement of all employees in completing the organizational culture assessment questionnaire.

6. Quite a common mistake made by managers is the lack of compilation of results after performing analyses by several methods and conclusions and making decisions based on fragmentary analysis results. Therefore, the last stage of the methodology should not be omitted. It is also suggested to list, apart from the results, selected main assets of the company, crucial for product and service integration, and to assess them in terms of sensitivity to weakening due to emerging threats. The threat, which could eliminate the main assets of the company in the area of product-service integration strategy, would eliminate all efforts and actions taken by the manufacturer in this direction.

7. Strategic analysis according to the proposed methodology should be carried out periodically - in larger companies even every year - due to the changing dynamic market conditions and development of companies.

\section{Conclusions}

A trend towards servitization can be observed mainly in the industry sector, however, it also manifests itself in other contexts and sectors of the economy, e.g., in the digitalization of public services processes [47]. Its importance increases and creates many opportunities and challenges both for the research field and development of the organization. Despite current trends, servitization is not obligatory for every manufacturer but may be a promising choice with fruitful outcomes in many spheres. Not only can it bring a more steady competitive advantage but also new experiences, relations, and organization evolvement. To make the servitization journey successful, it should be carefully planned and implemented based on the results of a solid and appropriately oriented strategic analysis. This was the aim of this study - to develop such a set of 
methods and tools that will enable to gather relevant and most needed information which facilitate the decision-making process concerning the scope of servitization in the manufacturing company and will be a solid base for servitization strategy building.

The contribution of this study to the management research field is two-fold. First, it contributes to the research field of servitization/product-service integration in the context of its strategic management. The study proved that the strategic analysis of certain areas of company activity returns in financial outcomes from a service activity. Second, the proposed methodology is a well-described set of tools and guidelines for the theory and practice of strategic management of the servitization process in the manufacturing sector. The novelty of this study manifests itself in a comprehensive approach to the process of strategic analysis focused on servitization. It also proposes an original tool for assessment of the orientation of organizational culture.

The author is aware of the limitation of this study, which is, for example, the limited scope of empirical research (a survey limited to one country and one manufacturing sector) or a very limited number and scope of application of the methodology (SME from one Polish sector - machinery manufacturing). This appeared to be a very interesting direction for future research - to verify the methodology in different sectors and large corporations. Nevertheless, the author believes that the developed methodology is a valuable set of tools with high applicable potential for manufacturing companies that would like to start or continue the journey towards becoming a service provider. Its results are cognitive and allow to gather basic information that will facilitate making decisions about the strategy, scope, and scale of the servitization process in the company.

\section{References:}

[1] Crozet, M., Milet, E., Should everybody be in services? The effect of servitization on manufacturing firm performance, Journal of Ecomonics \& Management Strategy, Vol. 26, 2017, pp. 820-841.

[2] Oliva, R., Kallenberg,R. Managing the transition from products to services, International Journal of Service Industry Management, Vol. 14, No. 2, 2003, pp. 160- 172.

[3] Kozlowska, J., What Influences the Servitization Process the Most? A Perspective of Polish Machinery Manufacturers, Sustainability, Vol. 12, 2020, 5056.

[4] Kamal, M. M, et. al., Servitization implementation in the manufacturing organisations:
Classification of strategies, definitions, benefits and challenges, International Journal of Information Management, Vol.55, No. 102206, 2020.

[5] Baines, T., Lightfoot, H., Evans, S., State- ofthe- art in product- service systems, Proceedings IMechE., Vol. 221 Part B: J. Engineering Manufacturing, 2007, pp. 1543- 1552.

[6] Manzini E., Vezzoli C., A strategic design approach to develop sustainable product service systems, Journal of Cleaner Production, Vol. 11, No. 8, 2003, pp. 851-857.

[7] Williams A., The Strategic Management of Product Service Systems, BRASS Centre, Cardiff 2005.

[8] Martinez, V., Bastl, M., Kingston, J., Evans, S., Challenges in transforming manufacturing organisations into product-service providers, Journal of Manufacturing Technology Management, Vol. 21, No. 4, 2010, pp. 449-469.

[9] Fliess, S., Lexutt, E., How to be successful with servitization - Guidelines for research and management, Industrial Marketing Management, Vol. 78, 2019, pp. 58-75.

[10] Ahamed, Z., Inohara, T., Kamoshida, A., The servitization of Manufacturing An Emirical Case Study of IBM Corporation, International Journak of Business Administration, Vol. 4, No. 2, 2013, pp.1826.

[11] Neely, A., Benedettini, O., Visnjic, I., The servitization of manufacturing: Further evidence, conference paper in: 18th European Operations Management, Association Conference, Cambridge, July 2011.

[12] Meier, H., Planning and Development of Industrial Product-Service Systems [in]: The Philosopher's Stone for Sustainability Proceedings of the 4th CIRP International Conference on Industrial Product-Service Systems, Springer, 2012.

[13] Nemoto, Y., Akasaka, F., Shimomura, Y., A Knowledge-Based Design Support Method for Product-Service Contents Design, [in]: The Philosopher's Stone for Sustainability Proceedings of the 4th CIRP International Conference on Industrial Product-Service Systems, Springer 2012.

[14] Pezzotta, G., Cavalieri, S., Gaiardelli, P., A spiral process model to engineer a product service system: An explorative analysis through case studies, CIRP Journal of Manufacturing Science and Technology, Vol. 5, 2012, pp. 214-225.

[15] Dess, G., Lumpkin, G.T., Eisner, A.B., McNamara, G., Strategic management: text and cases, seventh edition, McGraw-Hill Education, New York, 2014,

[16] Kałkowska, J. et al, Zarządzanie strategiczne. Metody analizy strategicznej z przykładami [ang, 
Strategic management. Strategic analysis methods with examples) Wydawnictwo Politechniki Poznańskiej, Poznań 2010. [in Polish]

[17] Greenacre, M.J. Correspondence Analysis in Practice, Academic Press, London, 1993.

[18] Ziout, A., Azab, A., Industrial Product service System: A case Study from the Agriculture Sector, Procedia CIRP, A. ol. 33, 2015, pp. 64-69.

[19] van Ostaeyen J., Neels B., Duflou J.R., Design of a product-service systems business model: Strategic analysis and option generation, [in:] Hesselbach, J., Herrmann C. (eds), Functional thinking for value creation. Proceedings of the 3rd CIRP International Conference on Industrial Product Service Systems, Springer, BerlinHeidelberg, 2011.

[20] Mathieu, V., Service strategies within the manufacturing sector: benefits, costs and partnership, International Journal of Service Industry Management, vol. 12, No. 5, 2001, pp. 451-475.

[21] Vaitkevičius, S., Merkys, G., Savanevičienè, A., Model of strategic analysis tools typology, Engineering Economics, Vol. 47, No. 2, 2006, pp. 99-109.

[22] Kreutzer, R.T. Tools for the Strategic Analysis. In: Toolbox for Marketing and Management. Management for Professionals. Springer, Cham. 2019.

[23] Bock, A., Frank, U., Bergmann, A., Strecker, S. Towards Support for Strategic Decision Processes Using Enterprise Models: A Critical Reconstruction of Strategy Analysis Tools. In: Horkoff, J., Jeusfeld M., Persson A. (eds) The Practice of Enterprise Modeling. PoEM, Lecture Notes in Business Information Processing, Vol. 267, Springer, Cham, 2016.

[24] Grünig, R., Kühn, R. Strategic analysis and planning toolbox. In: Process-based Strategic Planning. Springer, Berlin, Heidelberg, 2011.

[25] Gierszewska, G., Romanowska, M., Analiza strategiczna przedsiębiorstwa,[Strategic analysis of a company] Polskie Wydawnictwo Ekonomiczne, Warsaw, 2014. [in Polish]

[26] Fisher, T. Gebauer, H., Fleisch, E., Service Business Development. Strategies for Value Creation in Manufacturing Firms, Cambridge University Press, New York 2012.

[27] Gebauer, H., Friedli T., Fleisch E., Success factors for achieving high service revenues in manufacturing companies. Benchmarking, An International Journal, Vol. 13, 2006, pp. 374-386.

[28] Meier, H., Roy, R., Seliger, G. Industrial Product-Service Systems - IPS2, CIRP Annals Manufacturing Technology, Vol. 59, 2010, pp. 607627.
[29] Tan, A.R., Matzen, D., McAloone, T., Evans, S. Strategies for Designing and Developing Services for Manufacturing, CIRP Journal of Manufacturing Science and Technology Vol. 3, No. 2, 2010, pp. 9097.

[30] Cohen, M. A., Agrawal, N., Agrawal, V., Winning in the aftermarket, Harvard Business Review, Vol. 84 No. 5, 2006, pp. 129-138.

[31] Kozłowska, J. Servitization of Manufacturing Companies - a Proposition of Factors for STEEPVL Analysis. In Economic and Social Development (Book of Proceedings), 23rd International Scientific Conference on Economic and Social Development (ESD); Cingula, M., Przygoda, M., Detelj, K., Eds.; Varazdin Development and Entrepreneurship Agency: Varazdin, Croatia, 2017; pp. 619-628.

[32] Nazarko, J., Ejdys, J., Halicka, K., Nazarko, Ł., Kononiuk, A. \& Olszewska, A. Factor Analysis as a Tool Supporting STEEPVL Approach to the Identification of Driving Forces of Technological Innovation. Proceedia Engineering, Vol. 182, 2017. pp. 491-496

[33] Ejdys, J., et al. Foresight in Higher Education Institutions: Evidence from Poland, Foresight and STI Governance, Vol. 13, No. 1, 2019, pp. 77-89.

[34] Szpilko, D., Foresight as a Tool for the Planning and Implementation of Visions for Smart City Development, Energies, Vol. 13 No. 7, 2020, 1782.

[35] Kononiuk, A. Glinska, E, Foresight in a Small Enterprise. A Case Study, Procedia - Social and Behavioral Sciences, Vol. 213, 2015, pp. 971-976.

[36] Szpilko D, Glińska E, Szydło J. STEEPVL and Structural Analysis as a Tools Supporting Identification of the Driving Forces of City Development, European Research Studies Journal, vol. 23, no. 3, 2020, pp. 340-363.

[37] Kozłowska, J. Servitization of manufacturing: Survey in the Polish machinery sector, Engineering Management in Production and Services, Vol. 12, No. 1, 2020, pp. 20-33.

[38] Klooster, S. A., Asselt, M. B. A., Practising the scenario-axes technique, Futures, Vol. 38, 2006, pp. $15-30$.

[39] Kononiuk, A., Metoda scenariuszowa w antycypowaniu przyszłości [eng. Scenario method in anticipation of the future], Organizacja i Kierowanie, Vol. 2, No. 151, 2012, pp. 33-48. [in Polish]

[40] Tan, A. R., When Product Life Cycle Meets Customer Activity Cycle, conference proceedings: $3 r d$ Research Conference on Relationship Marketing and CRM, 28-29.11.2007, Brussels, Belgium, available online https://orbit.dtu.dk/en/publications/ when-product-life-cycle-meets-customer-activitycycle. 
[41] Walker, H.T., Bourne, L., Shelley A., Influence, stakeholder mapping and visualization, Construction Management and Economics, Vol. 26, No. 6, 2008, pp. $645-658$

[42] de Sainte Marie, G., Kierowanie małym i średnim przedsiębiorstwem. 10 etapów [eng. Managing a small and medium-sized enterprise. 10 stages], Poltext, Warszawa 1993, [in Polish] [43] Szydło, J., Grześ-Bukłaho, J. Relations between National and Organisational Culture-Case Study. Sustainability vol. 12, no. 1522, 2020

[44] Szydło, J., Kulturowe ramy zarządzania [eng. Cultural management framework], Wydawnictwo Naukowe Sophia, Katowice 2018. [in Polish]

[45] Harrison, R. Understanding our Organizations Character, Harvard Business Review, vol. 5-6, 1994, pp. $119-128$

[46] Handy, Ch.B., Understanding Organizations, [Fourth Editions], Oxford University Press, 1993.

[47] Buics, L. Eisingerné Balassa, B. Servitization of public service processes with a simulation modelling approach. Engineering Management in Production and Services, vol. 12, no. 3, 2020, pp. 116-131.

\section{Sources of funding for research presented in a scientific article or scientific article itself}

This research was funded by the NATIONAL SCIENCE CENTRE, POLAND, grant number 2016/23/N/HS4/03547. The research was conducted within the scientific project "Methodology of strategic analysis of the company for the purposes of product-service integration".

\section{Creative Commons Attribution License 4.0 (Attribution 4.0 International, CC BY 4.0)}

This article is published under the terms of the Creative Commons Attribution License 4.0

https://creativecommons.org/licenses/by/4.0/deed.en_US 